extendida dentro del gremio, puesto que la mayor parte de los metales trabajados carecían de las marcas correspondientes al quinto y, por tanto, evadían al fisco. Consecuencia lógica de lo anterior era la falta, asimismo, de la marca del orfebre, lo cual dificulta el estudio estilístico de la platería que los autores realizan en el capítulo "La evolución formal de la platería quiteña”. No obstante, se ofrece en él un esbozo introductorio y panorámico de la influencia predominante del barroco sobre el rococó decorativo y el neoclasicismo, tendencias desarrolladas a lo largo de esta etapa. Cierran el apartado los estudios descriptivos y contextuales de las piezas cuyo autor ha sido identificado, todas ellas de carácter eclesiástico, rasgo que los investigadores atribuyen a que la autoridad civil no actuaría legalmente a pesar de tratarse también, en la mayoría de los casos, de metal que había evadido sus disposiciones tributarias. Acompañan a esta breve panorámica fotografías en blanco y negro de las piezas susodichas, así como un conjunto de 16 reproducciones fotográficas más, todas ellas eclesiásticas. En resumen, un significativo balance de la producción de los orfebres quiteños.

El último capítulo corresponde a la nómina anotada de plateros y batihojas ordenada alfabéticamente, que reúne bajo cada entrada el total de la información disponible hasta el momento sobre cada uno de los artesanos identificados, los maestros plateros y sus respectivos oficiales.

Cierra el volumen el apéndice que reproduce las Ordenanzas de Guatemala (I78I), documento que regía la actividad del gremio platero en todos sus aspectos, además del reglamento decretado por la Audiencia en 1779, efectivo sobre la jurisdicción de Quito.
Es de gran mérito la labor desarrollada por los autores, pues la investigación documental en el ámbito hispánico suele toparse con la carencia de fuentes merced a circunstancias sociales e históricas muy particulares, a la dispersión de documentos y testimonios, o a la imposibilidad de acceso a ciertos archivos o colecciones. El texto reseñado no estuvo libre de dichos obstáculos, mas resulta gratificante el empeño por reconstruir, así sea fragmentariamente, la nómina de los maestros mayores del gremio, la de los mayordomos de la cofradía, o aún más allá, la de los oficiales integrantes del taller de cierto maestro en un momento particular por medios indirectos (pp. I3I134). Si la tarea del historiador puede aspirar sólo a ofrecer aproximaciones parciales a realidades pretéritas, los autores han logrado obtener el máximo beneficio posible a partir de los recursos y la información disponibles a su empeño.

\section{s \\ El imaginario de Luis Márquez}

Alquimia, año 4, núm. Io, septiembre-diciembre de 2000

$$
\begin{gathered}
\text { por } \\
\text { FAUSTO RAMÍREZ }
\end{gathered}
$$

Fiel a sus tareas de conservación y rescate de los acervos que tiene bajo su custodia, el Instituto de Investigaciones Estéticas (Universidad Nacional Autónoma de México) ha llevado a cabo, en el transcurso de los últimos dos años, un par de empresas por 
DOI: http://dx.doi.org/10.22201/iie.18703062e.2000.76.2524

\section{6}

demás interesantes relacionadas con el acervo fotográfico de Luis Márquez Romay, depositado en las bóvedas de su Archivo Fotográfico Manuel Toussaint.

La primera de ellas fue la exposición organizada por Louise Noelle y Lourdes Cruz, formada por una selección de las fotos que de la ciudad de México y su arquitectura fue haciendo Márquez a lo largo de los años. La exposición, titulada Una ciudad imaginaria. Arquitectura mexicana de los siglos XIX y XX en fotografías de Luis Márquez, se presentó en diciembre de 1999 y tuvo por sede el así llamado Museo de Arquitectura, sito en el Palacio de Bellas Artes. Se publicó un bello catálogo, y es a éste al que quiero hacer primero una breve referencia. Marcada por el signo de la nostalgia por una ciudad ordenada y armoniosa, la de mediados del siglo $\mathrm{xx}$, todavía no devorada por el crecimiento anárquico y desmesurado que habría de padecer en los decenios posteriores, la selección que las curadoras nos ofrecen está constituida por un conjunto de imágenes de edificios de pulcra geometría, en calles extrañamente deshabitadas, o apenas transitadas acaso por contados peatones y vehículos. En este despoblamiento urbano, Márquez se nos antoja el heredero tardío de una tradición típicamente simbolista, fundada en México a principios del siglo xx en los óleos de Germán Gedovius y sus discípulos y que se confirma en los cuadros tempranos pintados en Europa por Diego Rivera y por Roberto Montenegro, o en los de Francisco Goitia durante su estancia barcelonesa. Varios otros ejemplos pictóricos podrían aducirse para corroborar lo dicho. Pero lo importante aquí es señalar las posibles raíces del imaginario de Luis Márquez en algunas de las propuestas iconográficas de los modernistas. Y esto sin olvidar que la fotografía arquitectónica de aquellos mismos años se caracterizaba igualmente por la ausencia, absoluta o casi, de presencias humanas vivas: pienso, por supuesto, en las bien conocidas visiones fotográficas de Guillermo Kahlo.

Ahora el Instituto de Investigaciones Estéticas, en coordinación con el Sistema Nacional de Fototecas del Instituto Nacional de Antropología e Historia, ha vuelto a hurgar en el rico acervo de los negativos de Márquez para proponernos otra versión de su labor fotográfica. El resultado es el número io de la revista Alquimia, cuya presentación nos reúne esta noche. Por invitación del editor de la revista, José Antonio Rodríguez, fungió de editor invitado Ernesto Peñaloza, encargado de la colección Márquez, junto con Adriana Roldán. El propósito de los editores era el de ofrecer, en lo posible, facetas variadas del "imaginario” de Márquez, que acaso vinieran a romper con el calificativo de "folklorista" proverbialmente asociado a su figura. Un calificativo que, hay que decirlo, el propio fotógrafo se ganó a pulso. Basta pensar en la inmensa colección de trajes regionales, unos auténticos y otros deformados o fabricados a la medida de sus deseos, que con una obsesión casi maniática fue acumulando a lo largo de varias décadas. $\mathrm{O}$ bien, en los dos libros que reúnen sendas selecciones de sus trabajos fotográficos con el objeto de "documentar" usos y tradiciones del "pueblo" mexicano. Me refiero, por supuesto, a Folklore mexicano, de 1950, y a El México de Luis Márquez, de 1978.

En un texto ejemplar, dentro de la brevedad exigida por los editores, Laura González cuestiona la falsa noción de la "transparencia" de la clásica foto marqueciana, que ha llevado a su calificación proverbial como 
"uno de los artistas reveladores de la realidad nacional". Márquez no "revela" sin más unas supuestas "esencias nacionales" con su talento escénico y fotográfico: construye un imaginario propio, conforme a ciertos presupuestos ideológicos, mediante el cual comunicaba su versión muy personal del México de la posrevolución a un público igualmente ávido de nutrirse de una imagen heroica y reverenciable.

José Antonio Rodríguez lo expresa muy bien en su texto introductorio:

Él fue un creador que ponía los signos en juego, no importando qué tanto se complementaban o se rechazaban entre sí. Es más, si no había una concordancia entre éstos no importaba porque en esencia lo que Luis Márquez quería ofrecer era su propia versión de los hechos, o sea, sus obsesiones, esto es, su propio imaginario Y sí, lo mismo en una puesta en escena [...] que en la puesta en cuadro [...], él iría creando su concepción de lo que México debía ser, su ideal escenográfico, ficticio, sobre la nación (p. 4).

Nunca se subrayará lo suficiente, a mi modo de ver, la relación familiar de Márquez con el teatro y su ambición perennemente frustrada de convertirse en cineasta. De alguna manera, esto queda señalado en los textos de Deborah Dorotinsky, Francisco Montellano y Aurelio de los Reyes, incluidos en la revista. Es evidente, en Márquez, una urgencia por la comunicación narrativa y dramática, una obsesión por la "puesta en escena" que le llevaba a convertir casi todo paisaje en "locación", para poblarlo de "actores" que escenificaban, con sus poses muy bien meditadas, un cuadro estático de gran intensidad dramática o de densa carga metafórica. Todos los recursos fotográficos estaban al servicio de semejante concepción.

Lo que yo quiero hacer aquí esta noche es poner a la consideración de ustedes otro elemento formativo en la estética visual de Márquez, que vino a complementar sus propensiones histriónicas. Tengo para mí que su visión de México arraiga profundamente en la que los modernistas pusieron en boga en el periodo de entresiglos. Si se ha repetido hasta el cansancio que las canciones de Agustín Lara representan una divulgación de la poética modernista para satisfacer las demandas expresivas y sentimentales de la cultura de masas; si el magnífico sentido ornamental del diseño que poseyó Ernesto García Cabral le permitió convertirse en uno de los más populares artistas gráficos hasta más allá del medio siglo $\mathrm{xx}$, ¿̨por qué no plantear la hipótesis de que el indiscutible protagonismo de Márquez en el campo de la fotografía "nacionalista", que tanta repercusión tuvo durante aquellas mismas décadas, tiene mucho que ver con la persistencia, en su obra, de los presupuestos estéticos simbolistas y decorativos que el modernismo puso en circulación al inicio del siglo xx?

La estilización casi dancística de las posturas que hace adoptar a sus modelos, por ejemplo, no sólo tiene que ver con el énfasis mímico del cine mudo (en cuya época de apogeo Márquez inició sus tareas como fotógrafo) sino, mucho también, con las poses estudiadas y exquisitas, rayanas en el amaneramiento, que los pintores modernistas exigían de sus modelos. Basta pensar en Saturnino Herrán, por ejemplo, y en las acciones tensas o lánguidas, con ecos miguelangelescos, que adjudicó a sus figuras. También Herrán supo gozarse en la 
DOI: http://dx.doi.org/10.22201/iie.18703062e.2000.76.2524

\section{8}

belleza del cuerpo humano desnudo, ya femenino (como lo hicieron los escultores de entresiglos y otros pintores), ya masculino (con una muy particular sensualidad, como también lo hizo Ángel Zárraga y, por supuesto, Márquez). La gracia adolescente y una cierta fragilidad andrógina se hallan tanto en Herrán como en la famosa serie de desnudos masculinos que Márquez ejecutó, y que José Antonio Rodríguez dio a conocer parcialmente en la revista Luna Córnea ("Márquez: Un universo idílico", en Luna Córnea, enero-abril de 1997, núm. II). Alquimia incluye algunas imágenes, sobre todo unos espléndidos desnudos femeninos, entre los cuales hallo algunos afines a los que de Nahui Ollin tomó Antonio Garduño (un artista, no lo olvidemos, que coincidió en las aulas de la Escuela Nacional de Bellas Artes con Herrán, igual que Alberto Garduño). Y, por cierto, en la relectura de Márquez que en Alquimia se hace, echo de menos un estudio puntual de sus tareas inaugurales como fotógrafo profesional en los años 20, y sus posibles relaciones con otros practicantes de algunas formas de “pictorialismo" en México.

Alquimia publica un desnudo femenino, de inspiración casi caligráfica, donde la mujer con el cuerpo en tensión extrema sostiene con ambas manos una calavera ( $\mathrm{p}$. 4). Aquí la semejanza con Ruelas es evidente, y evoca una de las siniestras letras capitulares que ornaban las planas de la Revista Moderna. Por lo demás, la asociación mujer-eros-muerte es uno de los tópicos más socorridos del pasado entresiglos artístico.

Entre las imágenes más sorprendentes que ahora se publican, está la de la página I8, dentro del fascinante artículo en que Itala Schmelz rescata la participación de
Márquez en la Exposición Mundial de Nueva York, en 1939-1940. La usual prestancia de la modelo vestida de tehuana que Márquez paseó por las instalaciones feriales parece competir aquí con la ferocidad de un león decorativo, de antiguo linaje babilónico, configurándose así una asociación mujer-fiera de larga tradición simbolista: esta femme fatale del trópico, caída como por ensalmo en Queens, se nos antoja una versión actualizada de las esfinges y mujeres leopardos y tigresas que pululan en los cuadros, dibujos y grabados del fin de siglo. La deliberada mezcolanza de lo antiguo y lo moderno, de la fuerza de las tradiciones vernáculas y los poderes de la invención tecnológica, que impregna como un leitmotif ésta y las demás fotos hechas por Márquez en la feria neoyorquina remite, en alguna medida, a la noción análoga del maridaje entre el norte y el sur continentales que Diego Rivera pintaría unos meses después en las instalaciones de otra gran feria mundial estadounidense, la de San Francisco en 1940 (The Golden Gate International Exposition), en un fresco titulado La unión panamericana. Pese a la aparente contradicción, conciencia de modernidad y nacionalismo no representaban polos antagónicos sino fenómenos complementarios en el proceso de construcción del Estado, del que nuestro fotógrafo ofrece su propia interpretación.

Y esto nos lleva a uno de los nexos más significativos que encuentro entre la visión nacionalista de Márquez y el modernismo. Conviene recordar aquellos "cuadros de arreglo" tan gustados en las primeras dos décadas del siglo $\mathrm{xx}$, con ejemplos memorables pintados por Herrán y por Gedovius: estudios de figuras rodeadas de elementos artesanales y/o arquitectónicos en que nuestros pintores pretendían cifrar una supuesta 
"alma nacional", muy relacionada con la idea del mestizaje entonces en gran circulación. Cuando Márquez hace posar a un o una modelo de apariencia "criolla" o mestiza, o de fuertes rasgos indígenas, que sostiene en las manos una batea, una olla de barro, un sombrero de palma o un guaje, nos parece que está recreando, con los recursos fotográficos, una composición de evidente intención metafórica, análoga a la de sus predecesores académicos. O bien, cuando procede a la "petrificación" de los indígenas, como califica en su artículo Deborah Dorotinsky a ese gusto por entremezclar lo etnológico con la arqueología y retratar a aquéllos contra un fondo de pirámides (pp. 9-IO), Márquez no sólo adapta procedimientos fotográficos puestos en circulación por Charnay o por Gamio: también invoca lo que tan bien supieron hacer Jorge Enciso y, sobre todo, Saturnino Herrán al yuxtaponer sus sinuosas figuras de adolescentes indios contra el fondo pétreo de alguna célebre escultura. Es cierto, a veces se percibe en Márquez un relativo grado de abstracción, una simplificación extrema de la "puesta en cuadro" que, aunada al uso de enaltecedores ángulos en contrapicado, ubican estas piezas de modo inconfundible en la década de los 20. Pero el propósito expresivo-ideológico subyacente, traducido en términos estéticos, remite sin duda a los paradigmas del modernismo. Acaso podría hablarse de un epimodernismo adaptado a la cultura de masas de la posrevolución.

En suma, el esfuerzo colectivo de repensar a Márquez que estuvo detrás de este número de Alquimia representa un paso importante en el necesario proceso de desmitificación de su figura y de su obra, y pone en evidencia la "opacidad" más que la "transparencia” semántica de aquel univer- so. Por otra parte, el catálogo de la exposición Una ciudad imaginaria y algunas de las reproducciones fotográficas incluidas en Alquimia nos demuestran la variedad del imaginario del artista. Como todo acervo extenso de negativos, sólo Dios sabe las sorpresas que el de Luis Márquez nos pueda deparar en lo futuro.

\author{
$\stackrel{3}{3}$ \\ La an-estética de la arquitectura \\ de Neil Leach
}

Barcelona-México, Gustavo Gili, 2001

(Título original: The Anaesthetics of Architecture, Cambridge, Massachusetts, MIT Press, 1999)

por

PETER KRIEGER

Neil Leach, director del programa de arquitectura y teoría crítica de la Universidad de Nottingham, Gran Bretaña, publicó en I999 un libro sobre la virtualización y estetización de la arquitectura actual. Dos años después, este ensayo de I44 páginas está en versión castellana. El gran público de lectores españoles y latinoamericanos, interesados en el análisis de la arquitectura contemporánea, tiene a su disposición una hipótesis interesante, aunque al elaborarse resultó un fracaso intelectual. Después de leerlo parece incomprensible que este texto haya podido aprobar los dictámenes de dos reconocidas casas editoriales, MIT Press y Gustavo Gili. 